УДК 343.98

DOI https://doi.org/10.32849/2663-5313/2020.7.62

Оксана Пчеліна,

докт. юрид. наук, дочент,

доцент кафедри кримінального процесу та організації досудового слідства

Харківського національного університету внутрішніх справ

\title{
ВИКОРИСТАННЯ СПЕЦІАЛЬНИХ ЗНАНЬ В ГАЛУЗІ ПСИХОЛОГІї У КРИМІНАЛЬНОМУ ПРОВАДЖЕННІ
}

У статті підкреслено, що особливої уваги заслуговують особливості використання спеціальних знань з різних галузей з урахуванням як специфіки механізму вчинення кримінальних правопорушень окремого різновиду, так і процесу їх досудового розслідування та судового розгляду. Проаналізовано наукові підходи до визначення поняття та сутності спечіальних знань.

Запропоновано під спечіальними знаннями в галузі психологї розуміти знання про особливості психологічної діяльності людини, якими володіє обізнана особа в результаті професійної психологічної підготовки та їх практичного застосування, що використовуються під час досудового розслідування кримінальних правопорушень і судового провадження з метою встановлення, пошуку та доказування вини особи злочиния, прогнозування поведінки учасників кримінального провадження та встановлення завданої протиправним діянням шкоди.

З'ясовано, що спечіальні знання в галузі психологї використовуються під час розслідування насильницьких, корисливо-насильницьких кримінальних правопорушень, а також у випадку вчинення протиправних діянь серійними злочиниями, неповнолітніми, членами організованих злочинних угруповань, вагітними жінками тощо.

Встановлено, що під час досудового розслідування названих вище категорій кримінальних правопорушень, а також судового провадження виникає необхідність у з'ясуванні психологічних складників таких протиправних діянь з метою всебічного, повного, об'єктивного та неупередженого дослідження всіх обставин кримінального провадження. Тому виникає необхідність використовувати як власні знання психології, так і звертатися за допомогою до обізнаних осіб - фахівиів у галузі психології.

Розглянуто особливості використання спеціальних знань у кримінальному провадженні взагалі та в галузі психології зокрема залежно від форм такого застосування - процесуальної та непрочесуальної. Розкрито значення використання залученими до кримінального провадження психологами методу психологічного портретування для визначення індивідуально-психологічних властивостей та особливостей поведінки особи.

Ключові слова: спеціальні знання, спеціальні знання в галузі психології, психологокриміналістичне профілювання, досудове розслідування, кримінальне провадження.

Постановка проблеми. 3 метою забезпечення ефективності кримінального провадження, яке полягає у вирішенні його завдань із суворим дотриманням основних вимог законодавства України, орган досудового розслідування, визначаючи основні напрями розслідування, а також вибираючи алгоритми своїх дій для вирішення слідчих ситуацій, що склалися, часто змушений приймати рішення про доцільність і необхідність використання спеціальних знань [1, с. 246].

Тому не виникає жодних заперечень і сумнівів з приводу того, що увага науковців до поглибленого дослідження інституту використання спеціальних знань у кримінальному провадженні не зменшуються, що є цілком закономірним [2, с. 188], адже використання спеціальних знань $є$ основним каналом впровадження у судово-слідчу практику досягнень науки й техніки [3, с. 164]. У зв'язку із зазначеним на особливу увагу заслуговують аспекти використання спеціальних знань із різних галузей з урахуванням як специфіки механізму вчинення кримінальних правопорушень окремого різновиду, так і процесу їх досудового розслідування та судового розгляду. Ось чому я вважаю важливим питання про використання спеціальних знань у галузі психології в кримінальному провадженні.

Аналіз останніх досліджень і публікацій. Поняття, сутність спеціальних знань, суб'єкти та форми їх використання в кримінальному провадженні неодноразово досліджували в своїх працях Н.А. Жерж, С.М. Лозова, Б.Є. Лук'янчиков, Є.Д. Лук'янчиков, 
В.М. Махов, О.В. Одерій, М.В. Салтевський, Р.Л. Степанюк, Ж.В. Удовенко, О.В. Ходанович, М.Г. Щербаковський та інші.

Незважаючи на беззаперечний вклад названих науковців у криміналістичну теорію, чимало питань залишаються спірними та не вирішеними. Зокрема, поняття, сутність і необхідність спеціальних знань постійно супроводжуються підвищеним інтересом вчених і продовжують залишатися дискусійними питаннями [4, с. 324]. Крім того, відсутне комплексне дослідження стану та перспектив використання в процесуальній і непроцесуальній формах спеціальних знань в галузі психології під час досудового розслідування кримінальних правопорушень і судового провадження. Тому в цій статті ставлю перед собою таке наукове завдання - визначити сутність спеціальних знань в галузі психології та особливості їх використання у кримінальному провадженні.

Виклад основного матеріалу. Використання спеціальних знань в галузі психології відіграє важливу роль у кримінальному провадженні, оскільки допомагає не тільки правильно кваліфікувати кримінальне правопорушення, а й висувати та перевіряти обгрунтовані слідчі версії, підвищувати ефективність тактики проведення слідчих (розшукових) дій і методичних рекомендацій, встановлювати детермінанти протиправних діянь $[5$, с. 11]. За допомогою використання спеціальних психологічних знань можна одержати дані, які дозволяють зрозуміти і правильно оцінити особливості психічної діяльності й поведінки людей, що має значення для висновків правового характеру [3, с. 165].

Щоб окреслити особливості використання спеціальних знань в галузі психології у кримінальному провадженні, вважаю за необхідне спочатку з'ясувати сутність понять «спеціальні знання» та «спеціальні знання в галузі психології». Характеризуючи спеціальні знання, окремі вчені акцентували увагу на тому, що вони не є загальнодоступними, ними володіє обмежене коло фахівців [6, с. 91]. У такий спосіб науковці вказують на те, що спеціальні знання фактично є професійними за своєю природою, тобто притаманними певним видам професійної діяльності [7, с. 46; 8, с. 42].

Так, В.М. Махов визначає спеціальні знання як знання, властиві різним видам професійної діяльності, за винятком тих, які $€$ професійними для слідчого й судді та використовуються в ході розслідування й розгляду кримінальних справ в суді з метою сприяння встановленню істини у справі у випадках і порядку, визначених чинним кримінальним процесуальним законодавством [7, с. 46].

М.В. Салтевський характеризує спеціальні знання як такі знання, вміння та навички, які постійно вдосконалюються; використовуються в будь-якій галузі людської діяльності; отримуються (набуваються) в процесі спеціальної освіти, досвіду і практичної діяльності (за винятком професійних знань осіб, які здійснюють розслідування); використовуються для забезпечення швидкого і повного розкриття і розслідування кримінального правопорушення, а також розгляду справи в суді [9, с. 184].

Є.Д. Лук'янчиков і Б.С. Лук'янчиков, визначаючи спеціальні знання, насамперед акцентують увагу на суб'єктах і цілях ïх використання [2, с. 189]. Ж.В. Удовенко наголошує на необхідності використовувати термін «спеціальні знання у процесуальному розумінні», під якими варто розуміти вміння і навики, набуті в результаті цілеспрямованої професійної підготовки і досвіду роботи, які використовують з метою збирання й дослідження інформації про кримінальні правопорушення, та які сприяють розробці засобів і прийомів роботи з доказами [10, с. 219].

М.Г. Щербаковський спеціальні знання визначає як неправову систематизовану інформацію з різних галузей наукової та практичної діяльності, якою володіє обізнана особа в результаті навчання або практичного досвіду з певної спеціальності й має відповідні вміння та навички її застосування для вирішення завдань, пов'язаних зі встановленням підстав для ухвалення уповноваженими особами процесуальних та організаційно-тактичних рішень у кримінальному провадженні [11, с. 48]. На мою думку, наведене вченим тлумачення спеціальних знань повністю відображає їх сутність i значення для кримінального провадження. Тому вважаю, що вказану дефініцію можна взяти за основу під час формування визначення поняття «спеціальні знання в галузі психології».

Як зазначають В.Я. Марчак, Л.Р. Шувальська, спеціальні знання експерта, спеціаліста та консультанта психологів - це психологічні теоретичні і методологічні знання про закономірності й особливості протікання і структури психічної діяльності людини, які мають юридичне значення, отримані в результаті спеціальної професійної психологічної підготовки і впроваджені в практику судової експертизи та практичного застосування, використовуються під час розслідування злочинів і при розгляді кримінальних справ у суді 3 метою сприяння встановленню істини в справі на підставах і в порядку, 
визначеному кримінально-процесуальним кодексом [3, с. 165-166].

Спеціальними знаннями в галузі психології є знання про особливості психологічної діяльності людини, якими володіє обізнана особа в результаті професійної психологічної підготовки та їх практичного застосування, що використовуються під час досудового розслідування кримінальних правопорушень i судового провадження 3 метою встановлення, пошуку та доказування вини особи злочинця, прогнозування поведінки учасників кримінального провадження та встановлення завданої протиправним діянням шкоди.

Спеціальні знання в галузі психології використовуються під час розслідування насильницьких, корисливо-насильницьких кримінальних правопорушень, а також у випадку вчинення протиправних діянь серійними злочинцями, неповнолітніми, членами організованих злочинних угруповань, вагітними жінками тощо, що пояснюється тим, що подія кримінального правопорушення та його розслідування - це складні, багаторівневі процеси, в межах яких важливої ролі набувають психологічні особливості певних осіб. Тому використання спеціальних знань в галузі психології є одним із чинників ефективності слідчої діяльності [12, с. 259].

Під час досудового розслідування названих вище категорій кримінальних правопорушень, а також судового провадження виникає необхідність у з'ясуванні психологічних складників таких протиправних діянь з метою всебічного, повного, об'єктивного та неупередженого дослідження всіх обставин кримінального провадження. 3 цією метою виникає необхідність використовувати як власні знання психології, так і звертатися за допомогою до обізнаних осіб - фахівців у галузі психології. Це дозволить з'ясувати як особливості формування особистості злочинця та його протиправної поведінки, так і особливості його поведінки під час здійснення кримінального провадження.

3 наведеного вище помітно, що спеціальні знання в галузі психології можуть використовуватися з різними цілями і в різних формах. При цьому в теорії кримінального процесу науковці пропонують виокремлювати форми, в яких можлива участь психолога у кримінальному процесі, 3 урахуванням саме способу надання ними допомоги сторонам кримінального провадження, їх ролі та процесуального статусу.

Зокрема, одні вчені пропонують виокремлювати чотири форми використання спеціальних знань у галузі психології в кримінальному провадження: проведення судово-психологічної експертизи та похідна від цього можлива участь експерта-психолога у процесуальних діях; участь психолога в ролі фахівця при провадженні слідчих і судових дій; участь психолога як альтернатива педагогу при допиті неповнолітніх підозрюваних, обвинувачених; довідково-консультативна діяльність психолога [13, с. 32-33]; а інші - три форми: залучення психолога в якості експерта для проведення судової експертизи; залучення фахівця в якості спеціаліста; консультація (довідково-консультаційна діяльність) [14, с. 118].

Більш розширений перелік форм використання спеціальних знань у галузі психології під час досудового розслідування розбоїв, вчинених неповнолітніми, надає О.Б. Яковіна. Вона пропонує виокремлювати такі форми використання вказаних знань: процесуальні: проведення судовопсихологічних (комплексних психологічних) експертиз; допит експерта-психолога щодо виданого ним висновку; участь фахівця-психолога у допиті, а також в інших слідчих (розшукових) діях за участі неповнолітніх; видача висновку спеціалістомпсихологом; і непроцесуальні: консультативно-довідкова діяльність психолога; використання власних знань у галузі психології особами, які беруть участь в таких кримінальних провадженнях [12, с. 260].

На мою думку, особливості використання спеціальних знань у кримінальному провадженні взагалі та в галузі психології зокрема варто розглядати залежно від форм такого застосування. При цьому я не поділяю погляд вчених, які штучно збільшують кількість таких форм. Їх всього дві й зумовлюються вони тим, нормами якого законодавства вони регламентуються. Тобто, якщо конкретні способи використання спеціальних знань, в тому числі в галузі психології, закріплені в положеннях Кримінального процесуального кодексу України, то йдеться про процесуальну форму, якщо ж іншими нормативно-правовими актами - то непроцесуальну. Тому в цій статті питання використання спеціальних знань у галузі психології будуть висвітлені, виходячи із наведеного вище твердження.

Процесуальними формами використання спеціальних знань у галузі психології є залучення фахівців-психологів до участі в проведенні окремих слідчих (розшукових) дій (зазвичай це допити); залучення експертівпсихологів для проведення судової експертизи; залучення фахівця-психолога в якості спеціаліста для надання висновків з питань, що належать до сфери його знань, під час 
досудового розслідування кримінальних проступків.

Таке використання спеціальних знань у галузі психології дозволить слідчому, дізнавачу, детективу отримати максимальний обсяг доказової інформації, вибрати правильну лінію поведінки під час спілкування 3 учасниками кримінального провадження під час проведення слідчих (розшукових) дій, встановити психологічний контакт з учасниками кримінального провадження.

На превеликий жаль, працівники органів досудового розслідування нехтують криміналістичними рекомендаціями 3 приводу доцільності та порядку використання спеціальних знань у галузі психології під час розслідування окремих категорій кримінальних правопорушень. Більше того, у випадку наявності обов'язкової процесуальної вимоги залучити психолога до проведення окремих процесуальних дій, слідчі підходять до її виконання формально. Вони залучають осіб, в яких є відповідна фахова освіта, при цьому не звертаючи уваги на їх спеціалізацію в галузі юридичної психології та наявність досвіду роботи з окремими категоріями осіб, наприклад неповнолітніми, засудженими, постраждалими від насильства тощо. Якщо ж вести мову про призначення судово-психологічних експертиз, в тому числі комплексних, то тут також ситуація $є$ плачевною, оскільки не у всіх кримінальних провадженнях, в яких це необхідно й рекомендовано окремими криміналістичними методиками, вона призначається.

Можливості судово-психологічної експертизи в кримінальному провадженні $€$ великими та важливими в процесі доказування, оскільки вона вивчає функціонування людини як особистості в різних видах iї діяльності та з урахуванням різних форм поведінки. Предметом такої експертизи $€$ цілісна особистість учасника кримінальної події, психологічний портрет якого важливий для встановлення об'єктивної істини в кримінальному процесі.

Вказана експертиза носить водночас і ретроспективний характер, оскільки ї̈ головним завданням є встановлення факту психічного життя суб'єкта в минулому, в юридично значущій ситуації, а перспективний характер дозволяе встановити глибину спричиненої психологічної шкоди, наявність і виразність дезадаптації, її зв’язок із фактом порушення прав, а також перспектив згладжування негативних наслідків, що надасть змогу слідчому й суду оцінити тяжкість злочинного посягання і буде мати кваліфікуюче значення [15, с. 171-173]. Тому вважаю, що потрібно частіше звертатися до такого про- цесуального інструменту збирання доказів у кримінальному провадженні, як призначення та проведення судово-психологічної експертизи.

Щодо непроцесуальних форм використання спеціальних знань у галузі психології, то вони зазвичай полягають у консультуванні 3 фахівцями-психологами 3 приводу окремих особливостей психологічної діяльності особистості та її виявів як у поведінці особи, так і в навколишньому середовищі, зокрема матеріальній обстановці.

Метою таких консультацій насамперед $€$ отримати відомості про невідомого злочинця, які б допомогли встановити його особу та припинити його протиправну діяльність; передбачити ймовірні варіанти поведінки особи з метою спланувати подальший хід розслідування; підготуватися до проведення слідчих (розшукових) дій, зокрема вибрати лінію поведінки та тактичні прийоми; прийняти рішення про призначення судово-психологічної експертизи та підготувати необхідні для іï проведення матеріали; отримати інформацію орієнтовного характеру про психологічні типи особистості та їх поведінку; забезпечити надання особі, найчастіше жертвам насильницьких кримінальних правопорушень, психологічну підтримку тощо.

Прикладом такої непроцесуальної форми використання спеціальних знань у галузі психології є отримання консультацій фахівців, які раніше проводили з потерпілими, особливо неповнолітніми потерпілими від сексуального насильства, а також підозрюваними різні види психодіагностики (особистісні тести, визначення рівня IQ та інші) для кращого вивчення їх особистості, характерологічних рис і використання отриманої інформації при підготовці та проведенні слідчих (розшукових) дій, насамперед допитів та одночасних допитів.

Так само можна використовувати в розслідуванні отримані результати і матеріали цих тестувань або за необхідності допитати як свідків вказаних фахівців. Такі дані можуть містити об'єктивну інформацію про особливості психологічного статусу потерпілого та/ чи насильника, за правильного їх використання слідчим можуть свідчити, наприклад, про неспроможність показань підозрюваного стосовно дружини як ініціатора домашніх сварок, які призвели до насильства щодо неї, або бути підтвердженням тому, що за своїх психологічних і психічних якостей саме підозрюваний був ініціатором всіх конфліктів, які 3 часом переросли в насильницькі дії щодо дружини та дітей [16, с. 16-17].

Окремої уваги заслуговує питання про використання залученими до кримінального 
провадження психологами методу психологічного портретування для визначення індивідуально-психологічних властивостей та особливостей поведінки об'єкта оперативного інтересу шляхом складання психологічного профіля [17, с. 7]. При цьому складання психологічних (психолого-криміналістичних) профілів є одним із методів використання спеціальних знань в галузі психології, який може застосовуватися як у процесуальній (за результатами проведення експертного дослідження чи судової експертизи), так в і непроцесуальній (отриманій на консультаціях) формах. Варто вказати і на той факт, що такі профілі можуть складатися як щодо відомих осіб (підозрюваного, потерпілого, свідка) для моделювання їх поведінки, що дозволить визначитися зі стратегією розслідування, тактикою проведення слідчої (розшукової) дії, зібрати необхідні сліди кримінального правопорушення та речові докази в кримінальному провадженні, так і стосовно невстановленого злочинця з метою його встановлення, пошуку та за необхідності розшуку.

\section{Висновки}

Отже, використання процесуальної та непроцесуальної форм спеціальних знань у галузі психології підвищує ефективність кримінального провадження, зокрема у справах про насильницькі, корисливо-насильницькі та вчинені неповнолітніми кримінальні правопорушення, оскільки забезпечує встановлення, пошук і доказування вини особи злочинця, прогнозування поведінки учасників кримінального провадження та встановлення завданої протиправним діянням шкоди.

\section{Список використаних джерел:}

1. Пчеліна О.В. Щодо питання використання спеціальних знань у кримінальному провадженні. Теорія і практика судової експертизи i криміналістики : збірник матеріалів III-ої Всеукраїнської науково-практичної конференції (м. Київ, 27 лютого 2020 року). Київ-Маріуполь, 2020. C. $246-249$.

2. Лук'янчиков Є.Д., Лук'янчиков Б.Є. Щодо поняття спеціальних знань та форм їх використання у кримінальному провадженні. Теорія $i$ практика судової експертизи і криміналістики : збірник матеріалів III-ої Всеукраїнської науково-практичної конференції (м. Київ, 27 лютого 2020 року). Київ-Маріуполь, 2020. С. 187-192.

3. Марчак В.Я., Шувальська Л.Р. Використання спеціальних психологічнихзнань суб'єктами судочинства. Юридична психологія та педагогіка. 2012. Вип. 1. С. 164-173.
4. Якіміва В.С., Пашура А.Ю. Спеціальні знання та їх межі: актуальне питання теорії судової експертизи. Теорія і практика судової експертизи $і$ криміналістики : збірник матеріалів III-ої Всеукраїнської науково-практичної конференції (м. Київ, 27 лютого 2020 року). Київ-Маріуполь, 2020. C. $324-326$.

5. Сорокотягин И.Н. и др. Использование специальных познаний при расследовании преступлений : учеб. пособие / отв. ред. Ф.В. Глазырин. Свердловск : УрГУ, 1978. 80 с.

6. Эйсман А.А. Заключение эксперта (структура и научное обоснование). М. : Юрид. лит., 1967. $152 \mathrm{c}$.

7. Махов В.Н. Использование знаний сведущих лиц при расследовании преступлений : монография. М. : РУДН, 2000. 296 с.

8. Степанюк Р.Л. Поняття спеціальних знань у кримінальному провадженні. Вісник Луганського державного університету внутрішніх справ імені Е.О. Дідоренка, 2014. Спецвип. С. 38-42.

9. Салтевський М.В. Криміналістика (у сучасному викладі) : підручник. К. : Кондор, 2008. 588 с.

10. Удовенко Ж.В. Криміналістика : конспект лекцій / за заг. ред. В.І. Галагана. К. : «Центр учбової літератури», 2016. 320 c.

11. Криміналістика : підручник: у 2 т. Т. 1 / А.Ф. Волобуєв та ін.; за заг. ред. А.Ф. Волобуєва, Р.Л. Степанюка, В.О. Малярової; МВС України, Харків. нац. ун-т внутр. справ. Харків, 2018. 384 с.

12. Яковіна О.Б. Використання спеціальних психологічних знань при розслідуванні розбоїв, вчинених неповнолітніми. Науковий вісник публічного та приватного права. 2016. Випуск 3. С. 259-262.

13. Мифтахова Л.А. Проблемы участия психолога в уголовном процессе : дис. канд. юрид. наук: 12.00.09. Уфа, 2001. $222 \mathrm{c}$.

14. Костицкий М.В. Использование специальных психологических знаний в совестком уголовном процессе : дис. д-ра юрид. наук: 12.00.09. Львов, 1990. 457 с.

15. Ходанович О.В. Сучасні проблеми судовопсихологічної експертизи неповнолітніх. Вісник Академії адвокатури України. 2014. Том 11. Число 3 (31). С. 170-178.

16. Александренко О.В. Сучасні можливості судових експертиз і напрями використання спеціальних знань при розслідуванні злочинів, пов'язаних із домашнім насильством. Теорія $i$ практика судової експертизи і криміналістики : збірник матеріалів III-ої Всеукраїнської науковопрактичної конференції (м. Київ, 27 лютого 2020 року). Київ-Маріуполь, 2020. С. 14-18.

17. Седнев В.В., Ирхин Ю.Б., Одерий О.В., Коструб А.Н. Методология психологического портретирования при раскрытии и расследовании серийных насильственных преступлений: итоги и перспективы развития. Криміналістичний вісник. 2012. № 1 (17). C. $6-14$. 
Oksana Pchelina. The use of special knowledge in the field of psychology in criminal proceedings

In the article has been emphasized that the peculiarities of the use of special knowledge in various fields deserve special attention, taking into account both the specifics of the mechanism of committing criminal offenses of a particular kind, and the process of their pre-trial investigation and trial. Scientific approaches to defining the concept and essence of special knoweledge have been analyzed.

It has been proposed to understand special knowledge in the field of psychology as knowledge about the peculiarities of psychological activity of a person possessed by a knowledgeable person as a result of professional psychological training and their practical application, used during pre-trial investigation of criminal offenses and court proceedings to establish, search and prove guilt, forecasting the behavior of participants in criminal proceedings and establishing the damage caused by the wrongful act.

It has been found that special knowledge in the field of psychology is used in the investigation of violent, mercenary-violent criminal offenses, as well as in the case of illegal acts committed by serial criminals, minors, members of organized crime groups, pregnant women, etc.

It has been established that during the pre-trial investigation of the above categories of criminal offenses, as well as court proceedings, there is a need to clarify the psychological components of such illegal acts in order to comprehensively, fully, objectively and impartially investigate all circumstances of criminal proceedings. To this end, there is a need to use both their own knowledge of psychology and seek help from knowledgeable people - specialists in psychology.

The peculiarities of the use of special knoweledge in criminal proceedings in general and in the field of psychology in particular, depending on the forms of such application - procedural and non-procedural, have been considered. The significance of the use of the method of psychological portrayal by psychologists involved in criminal proceedings to determine individual psychological properties and peculiarities of a person's behavior has been revealed.

Key words: special knowledge, special knowledge in the field of psychology, psychological and forensic profiling, pre-trial investigation, criminal proceedings. 